\title{
FUNCTION OF FIGURATIVE LANGUAGE FOUND IN GREYS ANATOMY'S MOVIE SCRIPT
}

\author{
Utari Fatchiyati ${ }^{1}$, Sujana $^{2}$ \\ ${ }^{1,2}$ Gunadarma University, Jl. Margonda Raya No. 100, Depok 16424, Jawa Barat \\ Corresponding Author(S): utrftch@gmail.com
}

\begin{abstract}
:
This research aims to identify types of figurative language found in some of Greys Anatomy's movie scripts and to identify the function of figurative language in some of Greys Anatomy's movie scripts. The source of the data in this research is the dialogue in Greys Anatomy. To achieve the aims of this research; the researcher uses the qualitative research method. The researcher uses the theory of Kennedy \& Perrine. The first result of this research is 100 data can be classified in Figurative Language, $7 \%$ Simile, 65\% Metaphor, 7\% Personification, 4\% Hyperbole, 9\% Understatement, 3\% Metonymy, and 5\% Paradox. The second result of this research is 92 data can be categorized as a function of figurative language. 14\% Imaginative Pleasure, 13\% Additional Imagery, $48 \%$ Emotional Intensity, and 25\% Means of Concentration.
\end{abstract}

Keywords:

Figurative language, function, movie script

\section{INTRODUCTION}

Language is one of the most important elements to communicate with each other, and it cannot be separated from every aspect of our life. According to Oxford Dictionary, language is defined as "a particular style of speaking or writing" or also known as "a way of expressing yourself or of saying something" (2015, p. 849). Based on the definition above, language is used to express ourselves, spoken or unspoken. Language can be used directly or indirectly. For example, we can find direct and indirect language in the film.

Based on Oxford Dictionary, film is "a series of moving pictures recorded with the sound that tells a story" (2015, p. 562). Usually, a film is used to entertain people, but nowadays, a film is also used to deliver some message or meaning, whether directly or indirectly. There are many genres of film. For example, action, adventure, animated, comedy, drama, fantasy, historical, horror, sci-fi, etc.

As mentioned before, language can be used directly or indirectly. Same as film, the director usually conveys an explicit or implicit message through the film. The implicit meaning in a film can be analyzed by using the form of figure of speech or figurative language. 
In this research, the researcher will focus on researching figurative language in some of Greys Anatomy episodes. The researcher chooses this film because many figurative languages can be found in Greys Anatomy film. The reason why the researcher chooses this topic is that figurative language is an exciting topic. It is often used in daily conversations with friends, relatives, or others; our parents often use figurative language hyperbola to scold us. The researcher uses the theory of Kennedy.

The problem of this research is what are types of figurative language found in some of Greys Anatomy's movie scripts and what are the functions of the figurative language in some of Greys Anatomy's movie scripts. The significance of this research is to analyze the implicit meaning of a film and prove that film is not for entertainment only but also delivers a message.

Based on Oxford Dictionary, figure of speech or figurative language is "a word or phrase used differently from its usual meaning" (2015, p. 561). Through figurative language, we can learn about the implicit meaning that is used in a song. It also helps us understand the difficult lyrics and learn about the explicit or implicit meaning that is delivered in a song.

Anatomy's Grey is an American medical drama television series that premiered on March 27, 2005. It tells us a story about Dr. Meredith Grey as an intern and later becomes the chief of general surgery. The series and the cast have been nominated in 61 awards and won 11 awards.

First, the research on Figurative Language was done by Heny Listiani from State Institute for Islamic Studies Salatiga. Entitled An Analysis of Figurative Language Found on the Somg Lyric by Taylor Swift's "speak now" Album. Her research aims to find the type of figurative language used in Taylor Swift's "SPEAK NOW" Album. This research use theory of Kennedy.

Second, the research on Figurative Language was done by Daniel Jerry Christian from Sanata Dharma University. Entitled Functions of Comparative Figurative Language Found in the Utterances Produced by The Elemental Spirits in "DOTA 2". His research aims to find and analyze the figurative language that is uttered by the characters in "DotA 2 " that contains figurative language and to find the functions of the comparative figurative language that are used by the characters of the elemental spirits in "DotA 2". This research use theory of Perrine.

Third, the research on Figurative Language was done by Dimas Anggit Prawiro from Semarang University. Entitled Figurative Language in Selected Songs Lyrics of Maher Zain. His research aims to find out the types of figurative language used in selected songs lyrics of Maher Zain and to find out the function of the most frequent figurative language found in selected songs lyrics of Maher Zain. This research use theory of Perrine and Leech.

Forth, the research on Figurative Language was done by Andreas Tri Hartana from Sanata Dharma University. Entitled An Analysis of the Translation of Figures of Speech Found in Coco Movie. His research aims to find out what are types of figures of speech that 
found in COCO movies and to find out how acceptable the translation of the figures of speech in the Indonesian subtitle. This research use theory of Abrams.

Fifth, the research on Figurative Language was done by Siti Aisah from Indonesian University. Entitled Metafora dalam Lagu Iwan Fals yang Bertemakan Kritik Sosial. Her research aims to analyze metaphorical expressions in Iwan Fals' song lyrics seen from the semantic aspect and to find out what is the most dominant domain as the source domain to form metaphor in Iwan Fal's song. This research use theory of Lakoff and Johnson also Moeliono. Sixth, the research on Figurative Language was done by Vidyadhari Wikan Pribadi from Sanata Dharma University. Entitled An Analysis of Figurative Language Translation in The Pursuit of Happiness Movie. His research aims to find out what types of figurative language are found in The Pursuit of Happiness movie and to find out how acceptable are the translations of figurative language translated in the movie. This research use theory of Abram and Larson.

Semantic is a branch of study about language and how we understand the meaning behind it. In semantics, there are literal and non-literal meanings. As stated by Saeed (2016, pp. 3-5) says "Semantics is the study of meaning communicated through language, semantic also show how people communicate meanings with language". Kreidler (1998, p. 3) "Semantic is the systematic study of meaning" She also added "In semantic, we are not interested in intuitions or hints but we are interested when the language implicates some additional meaning" (p. 57)

In semantic, Leech distinguished seven types of meaning which are: conceptual meaning, connotative meaning, social meaning, affective meaning, reflected meaning, collocative meaning, and thematic meaning. Conceptual meaning is the central factor in linguistic communication and the starting point for the semantic specification of words. Connotative meaning is the communicative value an expression has to do with what it refers to. Social meaning is that a piece of language conveys the social circumstances of its use. Affective meaning is often explicitly conveyed through the conceptual or connotative content of the words used. Reflected meaning is what is communicated through association with another sense of the same expression of the meaning. Collocative meaning refers to the association of a word since its usual habitual cooccurrence with certain types of words. Thematic meaning is communicated by the way the speaker organizes the message.

Kennedy (1995, pp. 677-678) stated that "figurative language departs from the usual denotations of words, it is often state truths that more literal language cannot communicate". Tarigan in Wijayanti (2007) said that "figure of speech or figurative language is a form of rhetoric that use to persuade the listeners".

There are 10 types of figurative language mentioned by Kennedy (1995, p 680-688) which are Simile, Metaphor, Personification, Apostrophe, Hyperbole, Understatement, Metonymy, Synecdoche, Transferred Epithet, and Paradox

Simile is a comparison of two things that connected and express similarity by connective such as like, as or than. Metaphor is a statement that one thing is something else. Personification is a figure of speech in which a thing, an animal, or an abstract term is 
made human. Apostrophe is a way of addressing someone or something invisible. Hyperbole is an overstatement that contains an exaggeration effect. Understatement is implying more than it said. Metonymy is the name of a thing that is substituted with another that is closely associated with it. Synecdoche is the use of a part of a thing to stand for the whole of it. Transferred Epithet is a device of emphasis the poet attributes to another thing that is associated. Paradox is a self-contradictory statement.

There are four types of figurative language mentioned by Perrine (2019, pp. 33-34) which are Imaginative Pleasure, Additional Imagery, Emotional Intensity, and Means of Concentration.

Imaginative Pleasure is the ability of mind that proceeds by sudden leaps from one point to another. The mind takes delight in the sudden leaps". In other words, this function provides us the pleasure of imagination. Additional Imagery can be defined as descriptive language that engages the human senses, imagery can be literal or figurative. Emotional Intensity adds emotion along with information. Means of Concentration means we need to concentrate on key terms of a sentence to explain more in such as a short sentence.

\section{METHOD}

Qualitative research method is suited for obtaining specific data. According to Taylor, Bogdan, and DeVault (2016, p. 7) "qualitative methodology refers in the broadest sense to research that produces descriptive data". As said by Maruster and Gijsenberg (2012, p. 7) "qualitative research methods are used to address research questions that require explanation or understanding". Meanwhile, Patton (2002, p. 4) stated that the "qualitative research method has three kinds of data collection: (1) in-depth, open-ended interviews; (2) direct observation; (3) written documents. Qualitative findings usually through observation, interviewing, content-analysis, creativity, etc". This research uses a qualitative research method since this research is analyzing and describes the data by observing and content-analysis.

In this research, the researcher is using Greys Anatomy S1-S2 movie script as the main data. The source of data of this research is the dialogue in Greys Anatomy which shows figurative language and the data of this research is the figures of speech.

The procedure taken in collecting the data is: watching Greys Anatomy many times so the researcher can notice the dialogue that contains figurative language, reading the movie script of Greys Anatomy that contains figurative language, highlighting or underlining the dialogue in Greys Anatomy that contains figurative language.

The procedure taken in analyzing the data is: classifying figurative language that shows in the dialogue of Greys Anatomy, classifying four function of figurative language that shows in the dialogue of Greys Anatomy, interpreting the figurative language and function of figurative language that shows in the dialogue of Greys Anatomy, and drawing Conclusion

\section{RESULTS AND DISCUSSION}

After collecting the data from 24 episodes of Greys Anatomy's movie script, the researcher has found 100 data can be categorized as figurative languages such as Simile, 
Metaphor, Hyperbole, Paradox, Metonymy, Personification, and Understatement. From the 100 data, the researcher found 92 data that can be categorized in the function of figurative language, which are Imaginative Pleasure, Additional Imagery, Emotional Intensity, and Means of Concentration.

Table 1 Research Results

\begin{tabular}{lccccc}
\hline \multicolumn{1}{c}{$\begin{array}{c}\text { Figurative } \\
\text { Language }\end{array}$} & Data & $\begin{array}{c}\text { Imaginative } \\
\text { Pleasure }\end{array}$ & Additional Imagery & Emotional Intensity & $\begin{array}{c}\text { Means of } \\
\text { Concentration }\end{array}$ \\
\hline Simile & 7 & 1 & - & 23 & 22 \\
Metaphor & 65 & 12 & 4 & 3 & - \\
Personification & 6 & - & - & 4 & - \\
Hyperbole & 4 & - & 1 & 7 & - \\
Understatement & 9 & - & - & - & - \\
Metonymy & 3 & - & 12 & 5 & 23 \\
Paradox & 5 & 5 & & 44 & \\
Total & 100 & 13 & & & \\
\hline
\end{tabular}

\section{Figurative Language}

\section{Simile}

a. George: Lost five patients on the code team today. I feel like the angel of death. This dialogue is found in Greys Anatomy's movie script s1 ep2. It is included in Simile because there is an addition "like" in the second sentence. Angel in the dictionary is "a spirit who is believed to be a servant of God, and sent by God to perform a task", and in this dialogue, George is a human, so it cannot be possible he is a servant of God. He compares himself with the angel of death because every patient he touches is dead; like the definition of an angel, he performs a task to his patient, and his patient is dead.

b. We see injured bike riders everywhere.

Cristina: Oh, it's like candy, but with blood, which is so much better.

This dialogue is found in Greys Anatomy's movie script s1 ep3. It is included in Simile because there is an addition "like" to Christina's dialogue. Candy in the dictionary is "sweet food made of sugar and chocolate". In the dialogue, before, we know that the injured person is a bike rider, a person, there is no way a person is made of sugar and chocolate. So the bikers are compared with candy because their round helmet is shaped like candy.

\section{Metaphor}

a. Burke: So I heard we got a wet fish on dry land?

Bailey: Absolutely Dr. Burke.

This dialogue is found in Greys Anatomy's movie script s1 ep1. It is included in Metaphor because fish in the dictionary is "a creature that lives in water". Richard and Siti stated three elements in metaphor; vehicle, tenor, grounds.

Vehicle: Fish on dry land

Tenor: Dying

Grounds: Description of condition

From the definition above, a fish cannot live outside the water or on dry land. In this sentence, the hospital does not get a real fish, but Burke compares the patient with fish on dry land because the patient is dying.

b. Cristina: Wish he'd just go to the light already, so I can get on another case.

Izzie's shocked. 
This dialogue is found in Greys Anatomy's movie script s1 ep3. It is included in Metaphor because the light in the dictionary is "the energy from the sun, the lamp, etc.". Richard and Siti stated three elements in metaphor; vehicle, tenor, grounds.

Vehicle: light

Tenor: bright and white

Grounds: visualization of a place

In this dialogue, Christina is not talking about the true light; she compares heaven with light because heaven is filled with good people. Heaven is symbolized with white colour and brightness just like a light.

\section{Personification}

a. Shot of Seattle at night, clouds rolling in, then of Alex, in the spare beds + empty corridor area.

This dialogue is found in Greys Anatomy's movie script s1 ep1. It is included in Personification because rolling in the dictionary is "regular intervals over some time". Cloud is an inanimate object; rolling is something that usually human do. Clouds cannot roll like a human because clouds are inanimate objects. There is an addition of human attributes to an inanimate object which is the cloud.

b. MVO: Sometimes reality has a way of sneaking up and biting us in the ass.

This dialogue is found in Greys Anatomy's movie script s2 ep4. It is included in Personification because biting in the dictionary is "an act of using teeth". Biting is something that is usually connected with humans. However, in this sentence, The MVO said that reality is biting us in the ass. There is no way for reality (inanimate) to bite us. However, in this sentence, there is an addition of a human attribute to an inanimate object.

\section{Hyperbole}

a. Bailey: Montgomery-Shepherd, isn't it?

Derek: The point is she should be on her way home. (He stares at her) You're trying to drive me crazy aren't you?

This dialogue is found in Greys Anatomy's movie script s2 ep4. It is included in Hyperbole because crazy in the dictionary is "stupid or non-sensible". In the dialogue above, Derek is overreacting about what Bailey's do. Bailey just did a consult with his ex-wife, and he is overreacting about it. The truth is, Bailey does her job, and there is no way that Derek would be stupid or lose his mind just because Bailey did her job.

b. Alex: I know what chronic means. What kind of pain are you having?

Patient: Oh, man. The pain's bad. It's like a thousand samurai warriors stabbing swords into my spine. I'm allergic to aspirin...

This dialogue is found in Greys Anatomy's movie script s1 ep5. It is included in Hyperbole because samurai in the dictionary is "a member of powerful military class in Japan". In this dialogue, the patient is overreacting to his pain; if a thousand samurai warriors are stabbing him with swords, he will die already, and he would not be in the hospital.

\section{Understatement}

a. Alex: That's a gunshot.

Digby: Yeah.

Alex: We got a gunshot wound. We got to get him down to the pit. 
Digby: Uh, Digby. All right, but it isn't an emergency. I scheduled it.

This dialogue is found in Greys Anatomy's movie script s1 ep7. It is included in Understatement because Digby has a gunshot wound from the dialogue. As we know, a gunshot is dangerous for us. However, in the dialogue, Digby said it is not an emergency; he underestimates the gunshot wound left in his body and acts like it was nothing.

b. Adele: Oh you are in 5 kinds of trouble Mr. Man. (She walks up to him and gives a kiss on the cheek) You had brain surgery and didn't tell me?

Richard: It was just a small procedure.

This dialogue is found in Greys Anatomy's movie script s2 ep2. It is included in Understatement because Richard just had brain surgery; brain surgery is something big. Brain surgery could kill him and end his life. However, in this dialogue, Richard said to Adele that brain surgery is a minor procedure. However, the truth is his life is at risk.

\section{Metonymy}

a. Cristina: We're very clear.

Bailey: Good. You have any bourbon?

This dialogue is found in Greys Anatomy's movie script s1 ep5. It is included in Metonymy. Metonymy is the name of a thing that is substituted with another. In this sentence, Bailey asks for Bourbon. Bourbon in the dictionary is "a type of American whisky made with corn". In this sentence, Bourbon is a whisky brand, and it is included in metonymy because Bailey says Bourbon instead of a whiskey.

b. Bailey: Blocked bowels become necrotic bowels. Check with Dr. Burke. See if we can bump someone. Those Judys' gotta come out today.

This dialogue is found in Greys Anatomy's movie script s2 ep2. It is included in Metonymy because metonymy is the name of a thing that is substituted with another. Bailey says "those Judy's". Judy's is a type of premium play doll and limited dolls in the USA. In this sentence, Bailey said "Judy" instead of dolls because Judy represents the dolls.

\section{Paradox}

a. George: Oh, so he pointed a nail gun at his head on purpose? That makes me feel better.

This dialogue is found in Greys Anatomy's movie script s1 ep4. It is included in Paradox because when someone nailed a gun at his head, we should feel worried or sad or even mad about it. According to Kennedy, Paradox is a self-contradictory statement. However, in this sentence, George says that he feels better when a person pointed a nail gun at his head. So it is a paradox because his feeling is contradictory to the patient's condition.

b. MVO: We get bigger, we get taller, we get older. But for the most part, we're still a bunch of kids.

This dialogue is found in Greys Anatomy's movie script s2 ep18. It is included in Paradox because the MVO said that they get bigger, taller, and older. According to Kennedy, Paradox is a self-contradictory statement. However, the MVO added that they still have a bunch of kids. When we get bigger, taller, and older, we are not a child anymore, so adding the sentence "we are still a bunch of kids" became contradictory with the dialogue before. 


\section{Function of Figurative Language \\ Imaginative Pleasure}

a. Cristina: Which resident you assigned to? I got Bailey.

Meredith: The Nazi? Yeah, me too

It is included in imaginative pleasure because, in this dialogue, Meredith and Cristina compare Dr Bailey with Nazi. This utterance provides an imaginative pleasure to the readers to imagine how bad and mean Dr. Bailey is when they hear she is compared with Nazi.

b. Burke: So I heard we got a wet fish on dry land?

Bailey: Absolutely Dr. Burke

It is included in imaginative pleasure because this dialogue shows the metaphorical meaning of fish on dry land. This utterance provides an imaginative pleasure to the readers to imagine how suffering a fish that are dying on dry land.

\section{Additional Imagery}

a. Scene: Meredith lying in bed, staring at the ceiling. It is storming outside and her alarm starts buzzing

This dialogue gives us auditory imagery. This dialogue shows the depression of Meredith which only lying and staring at the ceiling. The sentence "alarm starts buzzing" shows how auditory imagery effectively makes readers perceive sounds an alarm buzzing.

b. Cristina: Wish he'd just go to the light already, so I can get on another case.

Izzie's shocked

This dialogue gives us visual imagery. Light in this sentence means heaven. The sentence "light" shows how auditory imagery effectively makes readers perceive light's visuals a bright place to go.

\section{Emotional Intensity}

a. George: Lost five patients on the code team today. I feel like the angel of death.

There is an emotion added as George spoke. George feels sad and regretful because every patient he takes care of died, so he added sorrow emotion while saying he like the angel of death.

b. Meredith: Complicated for me. I'm the intern sleeping with the attending. Bailey isn't speaking to me anymore.

There is an emotion added to Meredith dialogue. She feels anxious and worried by saying, "complicated for me", She is afraid of losing her job.

\section{Means of Concentration}

a. George: Well we have to do something. Meredith's become like an exhibit. (Cristina groans) Like the ... (to Izzie) hey. Like a zoo animal, like that rare panda that everyone stares at.

It is included in Means of Concentration because in this dialogue, the sentence "an exhibit" implies that she is compared with an exhibition that is usually held for art or music because her dirty relationship is exposed. The exhibit implies people who look at Meredith everywhere she goes.

b. George: He likes me likes me.

Alex: Go for it, man, get yours. I'm down with the rainbow. (George looks up, wideeyed) 
It is included in Means of Concentration because, in this dialogue, the word "rainbow" implies the gay's symbol. Alex is comparing George sexuality with the rainbow. Although rainbow means colour in the sky, it also implies meaning as LGBT because the rainbow is used in LGBT's flag.

\section{CONCLUSION}

The researcher uses Kennedy's theory to classify the data. The result of this research is the researcher found 100 data that can be classified in Figurative Language. The frequency of the data is data included in simile, metaphor, personification, hyperbole, understatement, metonymy, and paradox.

The researcher uses Perrine's theory to classify the data. The result of this research is the researcher found 92 data that can be categorized as a function of figurative language: imaginative pleasure, additional imagery, emotional intensity, and gives means of concentration.

In conclusion, the most figurative language found by the researcher is Metaphor. Moreover, the most function of figurative language found by the researcher is Emotional Intensity.

\section{REFERENCE}

Aisah, S. (2010). Metafora dalam lagu Iwan Fals yang bertemakan kritik sosial. Depok: Indonesian University.

Alice Deignan, J. L. (2013). Figurative language, genre and register. United Kingdom: Cambridge University Press.

Beaver, F. E. (2007). Dictionary of film terms: The aesthetic companion to film art. New York: Peter Lang Publishing.

Cain, S. B. (2014). A short guide to writing about literature. United States of America: Pearson Education.

Christian, D. J. (2019). Functions of comparative figurative language found in the utterances produced by the Elemental Spirits in "DOTA 2". Yogyakarta: Sanata Dharma University.

Gijsenberg, L. M. (2012). Qualitative research methods. California: SAGE Publications.

Glucksberg, S. (2001). Understanding figurative language: From metaphors to idioms. New York: Oxford University Press.

Harris, J. (2001). The learning paradox. New Jersey: Wiley.

Harris, R. A. (2003). Writing with clarity and style. New York: Pyrezak Publishing.

Hartana, A. T. (2018). An analysis of the translation of figures of speech found in COCO movie. Yogyakarta: Sanata Dharma University.

Hornby, A. S. (2015). Oxford advanced learner's dictionary of current English 9th edition. United Kingdom: Oxford University Press.

Kennedy, D. G. (1995). Literature: An introduction to fiction, poetry, and drama. New York: HarperCollins College Publishers.

Kurniawan. (2016). Interpretation of the associative meaning in the lyric of Maher Zain's selected song. Makassar: Alauddin State Islamic University of Makassar.

Listiani, H. (2015). An analysis of figurative language found on the song lyric by Taylor Swift's "SPEAK NOW" album. Salatiga: State Institute for Islamic Studies. 
Monahan, R. B. (2016). Looking at movies: An introduction to film. United States: W.W. Norton \& Company, Inc.

Munawwaroh, M. (2008). Functional semantics analysis on the language of adverstisements of well-known electronic products. Malang: State Islamic University of Malang.

Nunan, D. (2007). What is this thing called language? New York: PALGRAVE MACMILLAN.

Patton, M. Q. (2002). Qualitative research \& evaluation methods. California: SAGE Publications.

Peng, H. Y. (2007). Bilingual lexicography from a communicative perspective. Amsterdam: John Benjamins Publishing.

Pribadi, V. W. (2018). An analysis of figurative language translation in The Pursuit of Happyness movie. Yogyakarta: Sanata Dharma University.

Prihantini, A. (2015). Majas, idiom dan peribahasa superlengkap. Yogyakarta: Bentang B First.

Saeed, J. I. (2016). Semantics. United Kingdom: Blackwell Publishers.

Santas, C. (2002). Responding to film: A text guide for students of cinema art. United States: Burnham Inc., Publisher.

Shodiq, I. M. (2020). Type and meaning of figurative language of most popular football anthem song from English Premier League Club. Surakarta: Muhammadiyah University Surakarta.

Steven J. Taylor, R. B. (2016). Introduction to qualitative research methods. Canada: John Wiley \& Sons, Inc.

Sweetser, B. D. (2014). Figurative language. United Kingdom: Cambridge University Press.

Wijayanti, L. A. (2017). An analysis of figurative language used in Paulo Coelho's Adultery novel. Surakarta: Muhammadiyah University Surakarta.

Zhang, X. (2005). English rhetoric. Beijing: Tsinghua University Press. 